\title{
The Anthropologist
}

Seth Kramer, Daniel A. Miller and Jeremy Newberger, dirs. 81 mins. English, Russian, Sakha, Kiribati, Spanish, Quechua with English sub-titles. Ironbound Films, USA, 2016.

Sue Sudbury

Bournemouth University, UK

The Anthropologist clearly signposts in the opening sequence what it is about, as we watch Margaret Mead's daughter Mary watching archive footage of herself with her mother; the film begins as a tale of two anthropologists' daughters, and their relationships with their mothers. Mead's daughter, Mary, remembering her mother is intercut effectively with archive footage of them both, woven throughout the film to neatly frame anthropologist Susie Crate's relationship with her teenage daughter, Katie. The latter relationship forms the bulk of the film as we follow the two of them across continents while Crate, an academic at George Mason, conducts anthropological research.

Crate's daughter, Katie, is the result of Crate 'going native,' as she describes it, in Siberia. An intriguing and very human, though controversial, practice which is unfortunately just skimmed over within the film. Crate is now estranged from Katie's father and there does seem to be, judging by the expressions on Katie's face at one point, some residual resentment over her parent's relationship. But this tension is left unexamined by the filmmakers, and is surely a missed opportunity for deeper insights into their relationship. Katie talks about her identity and trying to fit into what looks like a predominantly white American neighbourhood where she lives with her mother. The film is shot over four years so we first see Katie at 14 and in the last shot she is 18 , so this longitudinal filming does provide the opportunity to explore the changing relationship between mother and daughter.

There is a particularly amusing exchange between the mother and daughter in which Crate announces to her daughter Katie that they are going for Christmas to the remote island of Kiribati in the South Pacific - a place which Katie exclaims, with disgust, has "no electricity". This teenage petulance contrasts with Margaret Mead's observation, revealed in the interview with her daughter, Mary, that in the South Pacific teenagers did not appear to fight with their parents.

As Crate embarks upon her research, additional layers of fascinating information is revealed as the film pivots from focusing on the mother and daughter relationship to exploring the role of an anthropologist. Through Crate's work, the film poignantly and dramatically shows the effects of climate change on communities across the globe. The cinematography here is of a particularly superb, paralleling between different geographical locations through the use of well-drawn shots and very sobering montages. There are moving sequences in which we hear local people talk of animals behaving strangely as evidence of climate change. The film humanises those affected by these changes and tells their stories with compassion. Crate's acute observation and sensitivity is framed by the interview with Mary (Mead's daughter) in which she praises her mother's "habit of noticing." 
The film raises many interesting issues about the role of the anthropologist and deftly illustrates the divide that exists when different cultures come together. At one point, Crate presents a gift to the people of the Kiribati islands in the South Pacific and then suddenly a few of the women present get up and spontaneously burst into song with much accompanied laughter. It is not clear whether the community are laughing 'with' or 'at' Crate. Her discomfort and unease is palpable. When one man says, "when you see your land is broken, there is a shaking in your heart" the subject of climate change is poetically brought back to sceptical Western audiences and a powerful image of Crate and two local villagers standing in water dramatically shows us how much the sea has risen.

Intended for a general audience, the Anthropologist is a very watchable, entertaining and fast-moving film that offers us an insight into the work of an environmental anthropologist. The editing style at the beginning is fast-paced, more in tune with a television series than a documentary, and the choice of accompanying music is bit predictable. In fact, it is the editing that makes the film feel bit disjointed at times - at the beginning inter-titles are used, though later discarded, and at one point split-screen is suddenly introduced as a storytelling technique. Some editorial opportunities were missed. For example, did Mary ever feel resentful of the fact that her mother (Margaret Mead) was "never not in 'the field". "My mother was very focussed on people", she continues, but was she extend that same focus to her daughter? These difficult questions were not asked or at least, if they were, the answers never made the final cut.

The cinematography is breath-taking, particularly when Crate and her daughter Katie travel to the Peruvian Andes and Crate climbs up with local villagers onto a glacier to collect ice. This is a very strong sequence with the dramatic visual images combining with Crate's almost 'poetic' voiceover in which she talks of the glacier expressing its anger at people who have caused it to melt. Once again the use of music here detracts from the power of the words and images. Diegetic sounds alone would have sufficed and been more powerful.

The film ends neatly with Crate waving her daughter, Katie goodbye as she leaves to study anthropology at a university; a subject, that earlier in the film, her younger teenage-self had so categorically rejected. The fledging anthropologist acknowledges that she has changed and finds hope in this, and in that we all need to change in order to reduce climate change.

The Anthropologist is an intriguing and memorable film about environmental anthropologists and the important work they do collecting and telling the stories of people whose lives are being reshaped by climate change. It is also about the relationship between female anthropologists and their daughters. As such, it does an important job of introducing the subject and will no doubt generate discussion but it is not an anthropological film, and neither does it claim to be. 